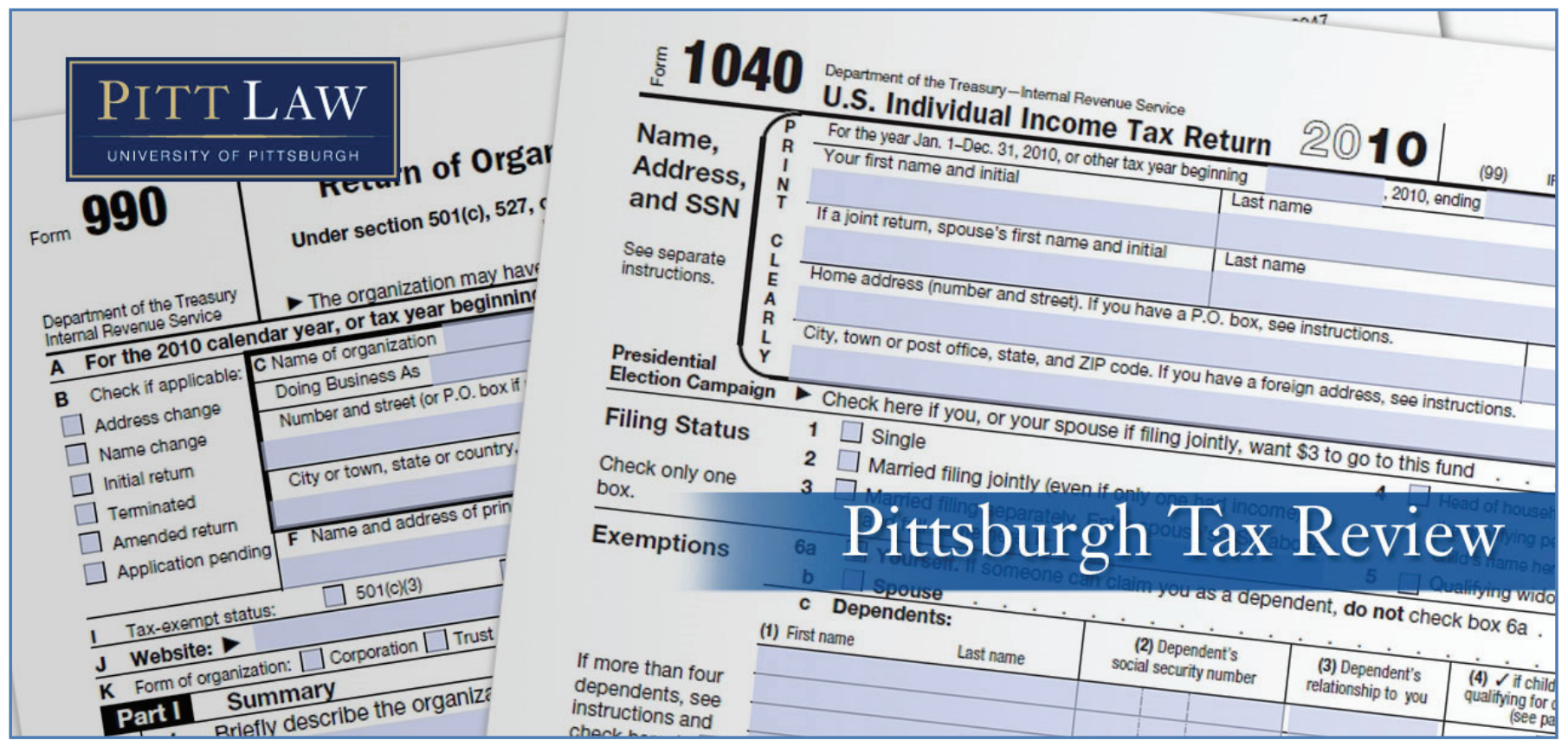

Volume 10 (2013) | ISSN 1932-1821 (print) 1932-1996 (online)

DOI 10.5195/taxreview.2013.17 | http://taxreview.law.pitt.edu

\title{
NOTE
}

\section{AVOIDING DELEGATION DOCTRINE CHALLENGES TO INTERNET SALES TAX LEGISLATION: LESSONS LEARNED FROM THE MAIN STREET FAIRNESS ACT}

\author{
Michael J. Bouey
}

\section{(oc) EY-NC-ND}

This work is licensed under a Creative Commons Attribution-Noncommercial-No Derivative Works 3.0 United States License.

\section{ULLS D-Sull}

This journal is published by the University Library System of the University of Pittsburgh as part of its D-Scribe Digital Publishing Program, and is cosponsored by the University of Pittsburgh Press. 


\title{
NOTE
}

\section{AVOIDING DELEGATION DOCTRINE CHALLENGES TO INTERNET SALES TAX LEGISLATION: LESSONS LEARNED FROM THE MAIN STREET FAIRNESS ACT}

\author{
Michael J. Bouey*

\section{INTRODUCTION}

For almost two decades now, remote retailers have avoided the collection of state sales tax from otherwise taxable transactions merely because they have no physical presence within a particular state. With rapid technological advances, the United States is now experiencing a substantial increase in consumer use of the Internet as a commercial medium, ${ }^{1}$ making physical presence even less necessary for conducting retail business. Thus, many states have encountered an overwhelming decrease in sales tax revenue. $^{2}$ Additionally, the increased use of the Internet for retail transactions has caused a rift between retailers operating online and those with physical locations (so-called "brick-and-mortar" retailers) because of the unfair advantage that online retailers possess concerning the collection and remittance of state sales tax.

States' hopes to require remote retailers to collect sales tax were dashed by the Supreme Court's decision in Quill Corp. v. North Dakota. ${ }^{3}$

\footnotetext{
${ }^{*}$ Graduate of the University of Pittsburgh School of Law, 2013.

${ }^{1}$ Statistics show that the current status of Internet retail transactions, or "eCommerce," amounts to $8 \%$ of the total market, and is expected to rise at a steady increase amount to $9 \%$ in the year 2016 . See Sucharita Mulpuru, US Online Retail Forecast, 2011 to 2016 (Feb. 27, 2011), Forrester Research, Inc.

${ }^{2}$ See Donald Bruce et al., State and Local Government Sales Tax Revenue Losses from Electronic Commerce, 52 St. TAX NOTES 537 (2009).

${ }^{3} 504$ U.S. 298 (1992).
}

Pitt Tax Review | ISSN 1932-1821 (print) 1932-1996 (online) DOI 10.5195/taxreview.2013.17 | http://taxreview.law.pitt.edu 
To comply with the holding in the Quill Corp. decision and the demands of the dormant Commerce Clause, a state must establish a substantial nexus between the retailer and the taxing state. ${ }^{4}$ Establishing a substantial nexus has become more difficult with an increase in Internet accessibility, versatility, and mobility for both retailers and consumers. Conscious of this dilemma, the Court provided that the power to overrule the Quill Corp. decision lies strictly with Congress, ${ }^{5}$ since this is an area concerning transactions in interstate commerce. ${ }^{6}$

Recently, there have been several proposed bills that aim to resolve the inequalities between Internet and brick-and-mortar retailers under current state sales tax systems. During the 112th Congress, the most prominent among these bills was the Main Street Fairness Act, ${ }^{7}$ which permitted states to require remote retailers to collect sales tax from transactions with its residents. ${ }^{8}$ Proponents of the Act boasted that it established the best possible solution for recovering state revenue losses by drawing from the bursting vein of taxable transactions. Moreover, proponents claimed that Internet retailers' concerns about the burdens of compliance with the differing tax systems of several states were unwarranted and would be alleviated by the current increase in, and availability of, tax software. ${ }^{9}$ The Act attempted to mitigate these concerns by making a state's right to tax Internet sales transactions contingent upon the state's adoption of minimum tax simplification standards. ${ }^{10}$ In addition, however, the Act provided that in order for a state to reap the benefits of remote sales taxation, that state must also become a full member of the Streamlined Sales and Use Tax

${ }^{4}$ Id. at $310-12$.

${ }^{5} I d$. at $318-19$.

${ }^{6}$ Congress has been given an explicit grant of authority to regulate interstate commerce. See U.S. CONST. art. I, $\S 8$, cl. 3. See also Gibbons v. Ogden, 22 U.S. 1 (1824) (holding that the power to regulate interstate commerce belongs to Congress through the Commerce Clause in Article I).

${ }^{7}$ S. 1452, 112th Cong. (2011).

${ }^{8} I d . \S 4$.

${ }^{9}$ See Durbin, Conyers, Welch and Others Introduce Bill to Level the Playing Field for Main Street Retailers, DURBIN.SENATE.GOV (July 29, 2011), http://durbin.senate.gov/public/index.cfm/ pressreleases?ID=9f6a8a21-02d2-4385-917d-f86a8082de60.

${ }^{10}$ Main Street Fairness Act, S. 1452, 112th Cong. § 6 (2011).

Pitt Tax Review | ISSN 1932-1821 (print) 1932-1996 (online) DOI 10.5195/taxreview.2013.17 | http://taxreview.law.pitt.edu 
Agreement (SSUTA). ${ }^{11}$ Furthermore, the SSUTA imposes additional obligations upon a full member state, including submission to the decisions of the SSUTA Governing Board. ${ }^{12}$

The Main Street Fairness Act, while leaving state implementation wholly voluntary, would have provided the potential for significant revenue benefits to participating states but would also have demanded compliance with certain tax-related standards set by the SSUTA Governing Board. Because of these demands, the Act, if it had been passed, would likely have been subject to challenges under the delegation doctrine. Removing congressional delegation to the Governing Board and establishing concrete provisions using Congress' own legislative power could substantially avoid these challenges. With the induction of the 113th Congress, the Marketplace Fairness Act of 2013 has taken the forefront in proposed Internet sale tax legislation. ${ }^{13}$ The provisions of the Marketplace Fairness Act, although presumably unwittingly, ${ }^{14}$ have significantly reduced the potential for delegation challenges. However, whether the Marketplace Fairness Act will be enacted is yet to be determined. ${ }^{15}$ Therefore, future Internet sales tax legislation proposals, including a reintroduction of the Main Street Fairness Act during the 113th Congress, should be structured in

${ }^{11} I d . \S 4(\mathrm{a})(1)$. See generally Streamlined Sales and Use Tax Agreement, STREAMLINED SALES TAX GOVERNING BD., INC. (as amended May 24, 2012), available at http://www.streamlinedsalestax .org/uploads/downloads/Archive/SSUTA/SSUTA\%20As\%20Amended\%205-24-12.pdf [hereinafter SSUTA].

${ }^{12}$ See SSUTA, supra note $11, \S 1003$. See also Bylaws of the Streamlined Sales Tax Governing Board, Inc., StREAMlined SAles TAX GOverning BD., INC. (May 12, 2009), http:// www.streamlinedsalestax.org/uploads/downloads/Bylaws/SST_Bylaws_05_12_09.pdf [hereinafter Governing Board Bylaws]; Rules and Procedures, STREAMLinEd SALES TAX Governing BD., InC. (as amended Oct. 6, 2011), http://www.streamlinedsalestax.org/uploads/downloads/Rules/Governing \%20Board\%20Rules\%20\%20as\%20amended\%2010_6_11.pdf.

${ }^{13}$ See Marketplace Fairness Act of 2013, S. 743, 113th Cong.

${ }^{14}$ The Marketplace Fairness Act was first introduced in 2011, during the 112th Congress, alongside the Main Street Fairness Act. See Marketplace Fairness Act, S. 1832, 112th Cong. (2011). At the induction of the 113th Congress, the Marketplace Fairness Act was reintroduced with nearly the same provisions. Compare Marketplace Fairness Act of 2013, S. 743, 113th Cong., with Marketplace Fairness Act, S. 1482, 112th Cong. (2011). Therefore, it is unlikely that the differences between the Main Street Fairness Act and the current Marketplace Fairness Act are due to recognition of, and attempts to avoid, potential delegation doctrine challenges.

${ }^{15}$ The Marketplace Fairness Act of 2013 was passed by the Senate on May 6, 2013. However, the Act has yet to be passed by the House. See Marketplace Fairness Act of 2013, H.R. 648, 113th Cong.

Pitt Tax Review | ISSN 1932-1821 (print) 1932-1996 (online) DOI 10.5195/taxreview.2013.17 | http://taxreview.law.pitt.edu 
such a way that avoids the potential for challenges under the delegation doctrine.

Part II of this Note discusses the progression toward permissible Internet sales taxation, from Quill Corp. to recently proposed legislation. Part III examines potential delegation challenges that could have been made under the Main Street Fairness Act, which would likely have spurred extensive, costly, and unnecessary litigation. Part IV proposes revisions to Internet sales tax legislation that will aid in avoiding, or at the very least reducing, such unnecessary litigation. Finally, Part V concludes this Note.

\section{THE ROAD TO CONGRESSIONALLY APPROVED INTERNET SALES TAXATION}

\section{A. Quill Corp. v. North Dakota}

The Supreme Court's most recent decision regarding the collection of state sales tax from remote retailers is Quill Corp. v. North Dakota. ${ }^{16}$ In this case, the Court was concerned with a mail-order company that solicited its business through catalogs, advertisements, and telephone calls. ${ }^{17}$ North Dakota law required that any retailer, whether physically present or engaging in systematic solicitation of a consumer market in the state, collect sales tax from the consumer and provide it to the state. ${ }^{18}$ Since Quill Corp. received a portion of its profits from sales and advertising directed at North Dakota consumers, the state filed an action to require Quill Corp.'s payment of the sales tax that should have been collected. ${ }^{19}$

Although a state must establish minimum contacts and the existence of a substantial nexus, under the Due Process Clause and Commerce Clause respectively, to constitutionally compel the collection of state sales tax, the crux of the Supreme Court's decision is based upon the differentiation between these two concepts. ${ }^{20}$ The "minimum contacts" test is intended,

\footnotetext{
${ }^{16} 504$ U.S. 298 (1992).

${ }^{17} \mathrm{Id}$. at 302 .

${ }^{18} I d$. at $302-03$.

${ }^{19} \mathrm{Id}$.

${ }^{20}$ Id. at $306-13$.
}

Pitt Tax Review | ISSN 1932-1821 (print) 1932-1996 (online) DOI 10.5195/taxreview.2013.17 | http://taxreview.law.pitt.edu 
inter alia, to provide notice and fair warning, under the Due Process Clause, to out-of-state defendants that they are subject to suit in the forum state. It is established by simply finding a corporation's presence in the taxing state. ${ }^{21}$ Alternatively, in order to avoid implicating the dormant Commerce Clause, the taxing state must also establish a corporation's physical presence to determine the existence of a substantial nexus. Unless the taxing state can establish physical presence, it may not disrupt the structure of the national economy or impose burdens on interstate commerce. $^{22}$ In emphasizing the difference between these two tests, the Court stated that "a corporation may have the 'minimum contacts' with a taxing State as required by the Due Process Clause, and yet lack the 'substantial nexus' with that State as required by the Commerce Clause."23 Since Quill Corp. was not physically present in North Dakota, the Court upheld the substantial nexus test established in its earlier decisions and reversed the lower court's holding, which required Quill Corp. to collect and remit sales tax on transactions with North Dakota residents. ${ }^{24}$

In addition to the Supreme Court's continued support for the substantial nexus requirement, the Quill Corp. Court stated that Congress retained the power to disagree with the Court's conclusion and "decide whether, when, and to what extent the States may burden interstate mailorder concerns with a duty to collect use taxes." ${ }^{25}$ This caveat has lead to several efforts by states, politicians, and retailers to urge Congress to abandon the substantial nexus requirement for remote retail transactions.

\section{B. Responses to Quill Corp. Regarding Internet Sales Taxation}

Pursuant to the Supreme Court's decision in Quill Corp., several states have taken aggressive measures to require the collection of sales tax by remote retailers. Some states have enacted laws applying the substantial

${ }^{21}$ See Int'l Shoe Co. v. Wash., Office of Unemployment Comp. \& Placement, 326 U.S. 310 (1945) (explaining a corporation's presence within a state).

${ }^{22}$ Quill Corp., 504 U.S. at 312.

${ }^{23}$ Id. at 313 .

${ }^{24} I d$. at 319 .

${ }^{25}$ Id. at 318 .

Pitt Tax Review | ISSN 1932-1821 (print) 1932-1996 (online) DOI 10.5195/taxreview.2013.17 | http://taxreview.law.pitt.edu 
nexus requirement to the Internet retailers, within the confines of the Quill Corp. holding. Additionally, other states have created a coalition that attempts to simplify their tax structures and relieve Internet retailers' burden of compliance, as well as bait Congress into acting upon the authority granted by the Supreme Court to overrule the Quill Corp. decision. ${ }^{26}$ Such actions have recently led to several proposed bills that claim to resolve the current issues regarding Internet sales tax. ${ }^{27}$

\section{State Legislation in Compliance with Quill Corp.}

In an attempt to comply with the holding in Quill Corp., several states have either proposed or enacted legislation requiring the collection of sales tax by remote retailers. Many of these state laws consider affiliate marketing programs as satisfying the substantial nexus requirement. ${ }^{28}$ The first, and most notable, state action was an amendment to the New York State tax code in $2008 .^{29}$ The amendment is referred to as the CommissionAgreement Provision and provides that:

[A] person making sales of tangible personal property or services taxable under this article ("seller") shall be presumed to be soliciting business through an independent contractor or other representative if the seller enters into an agreement with a resident of this state under which the resident, for a commission or other consideration, directly or indirectly refers potential customers, whether by a link on an internet website or otherwise, to the seller.... ${ }^{30}$

Quelling any potential controversy regarding this amendment, the New York State Appellate Court, in a case against Internet retail giant, Amazon,

\footnotetext{
${ }^{26}$ See generally SSUTA, supra note 11.
}

${ }^{27}$ See generally Main Street Fairness Act, S. 1452, 112th Cong. (2011); Marketplace Equity Act, H.R. 3179, 112th Cong. (2011); Marketplace Fairness Act, S. 1832, 112th Cong. (2011); Marketplace Fairness Act, S. 743, 113th Cong. (2013) (as of the date of this publication, the Marketplace Fairness Act is the only proposed act to be reintroduced in the 113th Congress).

${ }^{28}$ See, e.g., Amazon Associates, AMAZON.COM, https://affiliate-program.amazon.com (last visited May 17, 2013); Join the Overstock.com Affiliate Program Today, OverSTOCK.COM, http://www .overstock.com/20789/static.html (last visited May 17, 2012); eBay Partner Network, EBAY.COM, https://ebaypartnernetwork.com/files/hub/en-US/index.html (last visited May 17, 2012); see also FRANK Fiore \& SHAwn Collins, Successful AfFiliate Marketing For Merchants (Greg Wiegand et al. eds., 2001) (providing an in-depth look at the history and application of affiliate marketing techniques).

${ }^{29}$ N.Y. TAX LAW $§ 1101$ (McKinney 2008).

${ }^{30} I d$. § 1101(b)(8)(vi). 
held the amended statute constitutional. ${ }^{31}$ Following in the footsteps of the bold New York legislature, several states have adopted similar legislation based on the sales affiliate principle, including Rhode Island, ${ }^{32}$ North Carolina, ${ }^{33}$ Illinois, ${ }^{34}$ Arkansas, ${ }^{35}$ Connecticut, ${ }^{36}$ and California. ${ }^{37}$

Although these legislative attempts seem to meet the substantial nexus requirements, they have not been successfully implemented. A primary concern and threat is the removal of in-state sales affiliates by Internet retailers, effectively destroying the substantial nexus previously established with the taxing state. ${ }^{38}$ Internet retailers are making such threats because they contend that the collection of sales tax from all states with such legislation would impose a burden on them that is highly dissimilar from the collection of sales tax by brick-and-mortar retailers, a difference that places them at a competitive disadvantage.

\section{Streamlined Sales and Use Tax Agreement}

The Streamlined Sales Tax Project is an organization whose principle purpose is to simplify state sales and use taxes. In November 2002, it adopted the Streamlined Sales and Use Tax Agreement. ${ }^{39}$ The purpose of the SSUTA is "to simplify and modernize sales and use tax administration ... in order to substantially reduce the burden of tax compliance." 40

${ }^{31}$ Amazon, LLC v. State Dept. of Taxation and Finance, 913 N.Y.S.2d 129, 146 (2010).

${ }^{32}$ R.I. GEN. LAWS $§ 44-18-15$ (2012).

${ }^{33}$ N.C. GEN. STAT. § 105-164.8 (2009).

${ }^{34} 35$ ILl. COMP. STAT. ANN. 105/2 (LexisNexis 2012).

${ }^{35}$ S.B. 738, 88th Gen. Assemb., Reg. Sess. (Ark. 2011).

${ }^{36}$ CONN. Gen. STAT. § 12-407(a)(12) (2012).

${ }^{37}$ CAL. Rev. \& TAX. CODE $§ 6203$ (West Supp. 2013).

${ }^{38}$ See Michael Mazerov, New York's "Amazon Law": An Important Tool for Collection Taxes Owed on Internet Purchases, CENTER ON Budget AND POL’Y PRIORITIES (July 23, 2009), http:// www.cbpp.org/cms/index.cfm?fa=view\&id=2876_ftn12.

${ }^{39}$ Samantha L. Cowne, The Streamlined Sales and Use Tax Agreement: How Entrepreneurs Can Plan for the Uncertain Future of E-Commerce Sales Taxation, 4 ENTREPRENEURIAL BUS. L.J. 129, 133 (2009).

${ }^{40}$ SSUTA, supra note $11, \S 102$ (areas of aspired improvement include state level administration of sales and use tax collections, uniformity in state and local tax bases, uniformity of major tax base definitions, creation of a central electronic registration system, simplification of state and local tax rates,

Pitt Tax Review | ISSN 1932-1821 (print) 1932-1996 (online) DOI 10.5195/taxreview.2013.17 | http://taxreview.law.pitt.edu 
Although the SSUTA alone will not resolve all of the problems with remote sales taxation, as established in Quill Corp., it does signal to Congress that the burden of a multi-state sales tax collection should no longer be seen as a substantial burden on remote retailers. ${ }^{41}$ The creation of the SSUTA was derived from a joint endeavor by forty-four states and the District of Columbia; however, only twenty-four of these states have passed legislation conforming with the agreement. ${ }^{42}$ Currently, only twenty-one of those states have been registered with full member status. ${ }^{43}$

\section{Proposed Congressional Action}

With increased state action, both in enacting affiliate-based Internet sales tax legislation ${ }^{44}$ and the effort of several states in attempting to put the SSUTA into broad force, Congress seems to be receiving the hint that the lack of Internet sales taxation is a serious concern. Recently, there have been several proposed bills that act upon Congress' power to overrule the decision in Quill Corp. and permit states to require the collection of sales tax by remote retailers. The most prominent of these proposed bills have

uniform sourcing rules for all taxable transaction, simplified administration of exemptions, simplified tax returns, simplification of tax remittances, and protection of consumer privacy).

${ }^{41}$ See Nat'l Bella Hess, Inc. v. Dept. of Revenue of State of Ill., 386 U.S. 753, 759-60 (1967) for a description of the Supreme Court's concern for burdening remote retailers ("For if Illinois can impose such burdens, so can every other State, and so, indeed, can every municipality, every school district, and every other political subdivision throughout the Nation with power to impose sales and use taxes. The many variations in rates of tax, in allowable exemptions, and in administrative and record-keeping requirements could entangle [a company's] interstate business in a virtual welter of complicated obligations to local jurisdictions with no legitimate claim to impose 'a fair share of the cost of the local government."' (emphasis added)).

${ }^{42}$ See How Many States Have Passed Legislation Conforming to the Agreement?, STREAMLINED SALES TAX GOVERNING BD., INC., http://www.streamlinedsalestax.org/index.php?page=gen_3 (last visited May 15, 2013).

${ }^{43}$ According to the SSUTA website, "a full member state is a state that is in compliance with the Streamlined Sales and Use Tax Agreement through its laws, rules, regulations, and polices." See State Info: Streamline Sales Tax State Members, Streamlined Sales Tax Governing Bd., Inc., http://www.streamlinedsalestax.org/index.php?page=state-info (last visited May 15, 2013).

${ }^{44}$ See supra notes $29,32-37$.

Pitt Tax Review | ISSN 1932-1821 (print) 1932-1996 (online)

DOI 10.5195/taxreview.2013.17 | http://taxreview.law.pitt.edu 
been the Main Street Fairness $\mathrm{Act}^{45}$ and the Marketplace Fairness Act of $2013 .{ }^{46}$

\section{a. Main Street Fairness Act}

During the 112th Congress, the most prominent Internet sales tax bill was the Main Street Fairness Act, which was introduced by Senator Dick Durbin in July $2011 .^{47}$ The Act was essentially built upon the premise that "[s]tates that voluntarily and adequately simplify their tax systems should be authorized to correct the present inequities in taxation through requiring sellers to collect taxes on sales of goods or services delivered in-state, without regard to the location of the seller." 48 However, authorization to enforce the collection of sales tax by remote retailers was granted only to full member states of the SSUTA ${ }^{49}$ that remained in compliance with the SSUTA tax simplification requirements. ${ }^{50}$ To aid with the administration and operation of the SSUTA, the Streamlined Sales Tax Governing Board, Inc. was created. ${ }^{51}$ Under the Main Street Fairness Act, significant authority was delegated to the Governing Board. Such authority includes: the ability to more fully define the minimum tax simplification requirements of the Main Street Fairness Act; ${ }^{52}$ the authority to determine whether a state is compliant with these tax simplification requirements, and, therefore,

${ }^{45}$ S. 1452, 112th Cong. (2011). See id. §3(3) (the Act makes note of Congress' authority to enact this bill to regulate and equalize sales tax structures).

${ }^{46}$ S. 743, 113th Cong. (2013).

${ }^{47}$ See Main Street Fairness Act, S. 1452, 112th Cong. (2011).

${ }^{48} I d . \S 3(4)$.

${ }^{49}$ Id. §4(a)(1) ("Each Member State under the Streamlined Sales and Use Tax Agreement is authorized, subject to the requirements of this section, to require all sellers not qualifying for the small seller exception to collect and remit sales and use taxes with respect to remote sales sourced to that Member State under the Agreement." (emphasis added)).

${ }^{50}$ See id. $\S 4(\mathrm{c}) ;$ see also id. $\S 6$;SUTA, supra note 11, art. III.

${ }^{51}$ See Governing Board Bylaws, supra note 12, § 3.

${ }^{52}$ See Main Street Fairness Act, S. 1452, 112th Cong., $\S 6$ (2011). The standards listed in $\S 6$ of the Main Street Fairness Act, while stating that they are drawn from the SSUTA, lack the extensive definition provided by the SSUTA. The Governing Board will have the authority to amend the SSUTA in any way, so long as it remains within the extremely broad requirements of the Main Street Fairness Act.

Pitt Tax Review | ISSN 1932-1821 (print) 1932-1996 (online) DOI 10.5195/taxreview.2013.17 | http://taxreview.law.pitt.edu 
whether the state remains a member of the SSUTA and the Main Street Fairness Act; ${ }^{53}$ and the authority to define the "small seller exception" to the requirement to collect remote sales tax. ${ }^{54}$

\section{b. Marketplace Fairness Act of 2013}

The Marketplace Fairness Act of 2013, sponsored by many of those that backed the Main Street Fairness Act, shares the similar purpose of "restor[ing] States' sovereign rights to enforce State and local sales and use tax laws ..." in remote retail transactions. ${ }^{55}$ However, the Marketplace Fairness Act differs from the Main Street Fairness Act in two critical areas: (1) granting state authorization to collect remote sales taxes and (2) defining a small seller exception.

First, the Marketplace Fairness Act of 2013 does not require an interested state to be a full member state of the SSUTA. ${ }^{56}$ While the Act does allow a grant of authorization to a full member state of the SSUTA, it also provides an alternative method of obtaining authorization, which requires the non-member state to adopt and implement the minimum simplification requirements listed in the Act. ${ }^{57}$ Second, the Act avoids delegation of the power to define and implement the "small seller exception." The Act concretely defines the "small seller exception" outright, instead of passing on that duty to a committee or the SSUTA Governing Board. ${ }^{59}$

\footnotetext{
${ }^{53}$ See id. $\S 4(\mathrm{c})$ (discussing the Governing Board's authority to determine the status of Member States and whether these states remain in compliance with the tax simplification requirements under $\S 6)$.

${ }^{54}$ See id. $\S \S 6(\mathrm{a})(13)(\mathrm{C})(\mathrm{i})(\mathrm{I})$ (in reference to "[a] provision requiring that the minimum compensation required of a Member State. .." to give to a seller for expenses in administering sales use tax for that state, such compensation may be "[a]djusted in relation to changes in the size of the small business exemption adopted by the Governing Board." (emphasis added)), 6(a)(16) ("The minimum simplification requirements for the Agreement ... [includes a] uniform rule to establish a small seller exception to a requirements to collect...." (emphasis added)).

${ }^{55}$ Marketplace Fairness Act of 2013, S. 743, 113th Cong. (2013) (first sentence).

${ }^{56} I d . \S 2(\mathrm{a}),(\mathrm{b})$.

${ }^{57} I d$. § 2(b).

${ }^{58} I d$. $~ 2(\mathrm{c})$.

${ }^{59} \mathrm{Id}$.
}

Pitt Tax Review | ISSN 1932-1821 (print) 1932-1996 (online) DOI 10.5195/taxreview.2013.17 | http://taxreview.law.pitt.edu 


\section{Potential Delegation Doctrine Challenges to the MaIN STREET FAIRNESS ACT}

As established, Congress has the power to regulate and permit Internet sales taxation through the Commerce Clause. This is because requiring retailers with no physical presence in a state to collect sales tax would impose a burden on interstate commerce and implicate the dormant Commerce Clause. Thus, in acting upon the current dilemma in Internet sales taxation, Congress has the option to either broadly authorize the implementation of state legislation requiring remote retailers to collect sales tax or to grant such authority while imposing limitations in order to maintain stability and uniformity. In order to avoid any potential burdens on interstate commerce, it is in the best interest of Congress to impose limitations on, or requirements for, the appropriate implementation of state Internet sales tax legislation. This limiting approach was the apparent objective of the proposed Main Street Fairness Act. As discussed, the grant of taxing authority under the Main Street Fairness Act was intimately tied to a state's acceptance of, and compliance with, the SSUTA, as well as submission to the SSUTA Governing Board. ${ }^{60}$ However, because the Governing Board is a private entity, ${ }^{61}$ Congress' delegation of substantial power to the Governing Board would likely have raised questions regarding the appropriateness of such delegation under the delegation doctrine and whether the standards given to the Governing Board for guidance provided the necessary protections to prevent abuse and a lack of impartiality.

Under the delegation doctrine, Congress has a limited ability to delegate its legislative power to another governmental branch or other entity. ${ }^{62}$ Although the delegation doctrine seems to place strict limitations on Congress, the Supreme Court has rarely upheld a challenge to a congressional delegation, particularly in instances where Congress

${ }^{60}$ See supra Part II.B.2.

${ }^{61}$ Business Entity Detail: Streamlined Sales Tax Governing Board, Inc., TENN. SEC'Y OF STATE, http:/tnbear.tn.gov/Ecommerce/FilingDetail.aspx?CN=106067026062054144037149050163102176147 221104209 (last visited Feb. 14, 2013) (providing detailed information on the Streamlined Sales Tax Governing Board, Inc. as a non-profit corporation).

${ }^{62}$ BLACK'S LAW Dictionary 491 (9th ed. 2009); see also S. Doc. No. 108-17, at 73 (2004).

Pitt Tax Review | ISSN 1932-1821 (print) 1932-1996 (online) DOI 10.5195/taxreview.2013.17 | http://taxreview.law.pitt.edu 
delegates the power to fill in the details of an act. ${ }^{63}$ The Court has emphasized the need for such delegation stating that, "in our increasingly complex society, replete with ever changing and more technical problems, Congress simply cannot do its job absent an ability to delegate power under broad general directives." ${ }^{\prime 4}$ Therefore, the Court has generally rejected challenges to Congress' delegation to other branches of the federal government. ${ }^{65}$

While the majority of the Supreme Court cases dealing with congressional delegation concern delegation to the other branches of government, particularly the executive branch, there have also been cases discussing Congress' delegation to private entities. ${ }^{66}$ While still generally upheld, there have been cases in which the Court has disapproved of this type of delegation. ${ }^{67}$ The overarching issues with delegation to private entities are that "[e]ven though the Court has upheld some private delegation by reference to cases involving delegations to public agencies, some uncertainty remains as to whether identical standards apply"68 and whether "[t]he absence of ... [administrative] procedural protections, designed to ensure fairness - as well as the possible absence of impartiality ..."69 lends support for the need for closer scrutiny when reviewing congressional delegation to private entities. ${ }^{70}$ Therefore, when

${ }^{63}$ See S. Doc. No. 108-17, at 79 (2004) (discussing the Supreme Court's approval of Congress' delegation of power to fill in the details in early cases such as Wayman v. Southard, 23 U.S. 1 (1825)).

${ }^{64}$ J.W. Hampton, Jr. \& Co. v. United States, 276 U.S. 394, 406 (1928).

${ }^{65}$ See S. Doc. No. 108-17, at 74 (2004) (particularly, delegation to the executive, including the President and administrative agencies).

${ }^{66}$ Id. at $88-90$.

${ }^{67}$ For example, in Carter v. Carter Coal Co., 298 U.S. 238 (1936), the Court did not find fault with the delegation because it was to a private entity, but because the act in issue "delegated to private entities whose interests were adverse to the interests of those regulated, thereby denying the latter due process." S. Doc. No. 108-17, at 89 (2004). See also A.L.A. Schechter Poultry Corp. v. United States, 295 U.S. 495 (1935) (striking down delegation to a private entity because the statute lacked adequate standards).

${ }^{68}$ S. Doc. No. $108-17$, at 90.

${ }^{69} \mathrm{Id}$. The procedures lacking in a delegation to a private entity, as opposed to a public agency, are those required under the Administrative Procedure Act. Once such procedural protection is notice and comment rulemaking.

${ }^{70} \mathrm{Id}$.

Pitt Tax Review | ISSN 1932-1821 (print) 1932-1996 (online)

DOI 10.5195/taxreview.2013.17 | http://taxreview.law.pitt.edu 
Congress decides to delegate authority to a private entity, it should recognize that such delegation is likely subject to challenges by those regulated.

The Main Street Fairness Act, as conceived, was likely to be subject to serious delegation doctrine challenges regarding Congress' delegation of authority to the SSUTA Governing Board. The first challenge was likely to concern Congress' delegation to the Governing Board to "fill in the details" of certain provisions in the Act. ${ }^{71}$ In particular, there is significant concern regarding the determination of the "small seller exception." The Main Street Fairness Act referenced and necessitated the requirement that the SSUTA have an established small seller exception; ${ }^{72}$ however, this exception was not defined within the Act itself. Congress delegated the definitional parameters of what constitutes a "small seller" entirely within the discretion of the SSUTA. ${ }^{73}$ Under the SSUTA, one will find that the small seller exception is no more defined than in the Main Street Fairness Act. ${ }^{74}$ The SSUTA simply leaves all discretion and authority to define the exception with the SSUTA Governing Board. ${ }^{75}$ Moreover, the SSUTA requires the Governing Board to review the small seller exception every two years and permits adjustments to the definition annually with ninety days notice. ${ }^{76}$ Whether and how frequently such adjustments are made will certainly disturb remote retailers that are dissatisfied with Congress' broad delegation to a private entity. Depending on how close a retailer is to the

\footnotetext{
${ }^{71} \mathrm{Id}$. at 79 (providing a more full description and analysis of the delegation concept of "filling up the details").

${ }^{72}$ See Main Street Fairness Act, S. 1452, 112th Cong., §§ 4(a)(1), 6(a)(16) (2011).

${ }^{73}$ See supra note 54 and accompanying text.

${ }^{74}$ SSUTA, supra note $11, \S 610$ (providing criteria for consideration in determining which small sellers qualify for an exemption and provides standards for annual review of such determinations, but does not actually define what constitutes a "small seller"). Although some proponents of the Main Street Fairness Act believe that SSUTA $\S 609$ provides the definition of a "small seller exception," $\S 609$ is concerned only with the obligation of a Member State to compensate "small remote sellers" for the costs incurred from compliance with the SSUTA. Section 609 defines the term "small remote seller," but clearly states that such definition is "[f]or purposes of this section." Id. $\S 609$ (emphasis added). Therefore, the definition provided in $\S 609$ does not apply to the "small seller exception" established under $\S 610$.

${ }^{75} I d . \S 610(\mathrm{~A})$.

${ }^{76} I d . \S 610(\mathrm{~F})$.
}

Pitt Tax Review | ISSN 1932-1821 (print) 1932-1996 (online) DOI 10.5195/taxreview.2013.17 | http://taxreview.law.pitt.edu 
sales volume threshold satisfying the small seller exception, that retailer's responsibility to collect and remit sales tax on remote sales could shift from one year to the next. This would cause significant burdens regarding employment of necessary staff, as well as the acquirement and utilization of tax compliance software. Moreover, it is unlikely that the decisions of the Governing Board to adjust the small seller exception would involve opportunities for public comment, since private entities are not required to adhere to the Administrative Procedure Act. Additionally, although the Governing Board is representative of all Member States, any alterations to the SSUTA, such as defining the small seller exception, are made by a majority vote of the Governing Board, not a unanimous one. ${ }^{77}$ This voting structure, without community involvement, raises concern for lack of impartiality by the majority and fairness to the minority states and remote retailers.

Another potential challenge to Congress' delegation of power to the SSUTA Governing Board would have involved the standards provided by Congress to guide the Board's decisions. The delegation doctrine requires that, when Congress decides to delegate its legislative power, it must provide "intelligible standards" to guide the entity and construct a framework from which the delegated entity can successfully perform its legislative tasks. ${ }^{78}$ These standards

\begin{abstract}
insure[] that the fundamental policy decisions in our society will be made not by an appointed official but by the body immediately responsible to the people, [and] prevent[] judicial review from becoming merely an exercise at large by providing the courts with some measure against which to judge the official action that has been challenged. ${ }^{79}$
\end{abstract}

Examples of intelligible standards that have been approved by the Supreme Court include: "'just and reasonable,' 'public interest,' 'public convenience, interest, or necessity,' 'unfair methods of competition,' and 'requisite to protect the public health [with] an adequate margin of safety." "80 This list of

${ }^{77} I d$. $\S 806$ ("Except as otherwise provided in the Agreement, all actions taken by the governing board shall require an affirmative vote of a majority of the governing board present and voting." (emphasis added)).

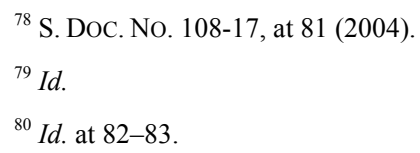

Pitt Tax Review | ISSN 1932-1821 (print) 1932-1996 (online) DOI 10.5195/taxreview.2013.17 | http://taxreview.law.pitt.edu 
intelligible standards is not exhaustive and, therefore, any intelligible standard not yet upheld by the Supreme Court is likely to be subject to challenge by those affected by Congress' delegation. The Main Stream Fairness Act would likely have been subject to challenges for lack of intelligible standards in two areas: the definition of the "small seller exception" and delegation to the SSUTA Governing Board to determine compliance.

Regarding the "small seller exception," congressional guidance on how to develop standards is almost entirely absent. While the guidelines and considerations provided in the SSUTA for establishing a definition of a "small seller" are reasonably well organized and clearly stated, the Main Street Fairness Act itself provided virtually no standards, intelligible or otherwise, for Congress' delegation. It may be that Congress was choosing to simply adopt the guidelines provided in the SSUTA. However, since those guidelines could very easily change at the will of the Governing Board, one can clearly see how a lack of congressional oversight could have been a potential subject of challenge brought by those affected by the Main Street Fairness Act.

Congress' delegation of authority to the SSUTA Governing Board to review and determine whether a Member State of the SSUTA meets the required, minimum tax simplification standards, and, therefore, whether a particular state was able to tax under the Main Street Fairness Act, would also likely have been subject to challenges for lack of intelligible standards. The Act merely states:

The authorization [to require remote sellers to collect and remit sales and use taxes] shall be granted once ... [e]ach Member State has met the requirements to provide and maintain the databases for sales and use taxes and the taxability matrix described in the Agreement, pursuant to requirements of the Governing Board. ${ }^{81}$

Unlike the definition of the "small seller exception," the SSUTA describes in immense detail the requirements that each state must accept in order to participate in the Agreement. ${ }^{82}$ With the ability to adjust and amend these requirements, the SSUTA Governing Board remained without intelligible

\footnotetext{
${ }^{81}$ Main Street Fairness Act, S. 1452, 112th Cong., § 4(a)(2)(C) (2011).

${ }^{82}$ See SSUTA, supra note $11, \S \S 301-34$.
}

Pitt Tax Review | ISSN 1932-1821 (print) 1932-1996 (online) DOI 10.5195/taxreview.2013.17 | http://taxreview.law.pitt.edu 
standards given by Congress under the Main Street Fairness Act. The lack of such standards, once again, would have availed the Main Street Fairness Act to delegation challenges that simplification requirements are subject solely to the will of the majority of the Governing Board.

\section{Proposed Solution to Limit Delegation Challenges to Future INTERNET SALES TAX LEGISLATION}

While it is likely that the Main Street Fairness Act would have withstood the potential challenges discussed above, the focus of this Note is not on whether these claims would have been successful, but to promote cognizance of the likelihood of such challenges actually being brought and the financial and efficiency burdens of unnecessary litigation that can be easily avoided in future Internet sales tax legislation, including a reintroduction of the Act during the 113th Congress, with a little legwork by Congress. Although the Main Street Fairness Act would have had a positive effect on the growing concern of Internet sales taxation, it failed to propose the most beneficent and logical solution. Congress' authority to overrule Quill Corp. does not necessarily require the implication of the states' right to manage their own sales tax systems. Moreover, this authority does not require Congress to delegate its legislative authority to a private entity. Congress is capable of placing direct requirements and limitations, clearly stated within the act itself, on the authorization of states' collection of remote sales tax.

In order to prevent extensive, unnecessary, and burdensome litigation surrounding potential delegation challenges to Internet sales tax legislation, Congress must eliminate the absolute reliance on SSUTA membership and its excessive dependence on the SSUTA Governing Board. The Marketplace Fairness Act of 2013 leads Congress in the right direction by giving states an option between membership with the SSUTA and compliance with a minimum set of requirements for reorganization of the state's sales tax structure. ${ }^{83}$ While state membership with the SSUTA should still authorize the use of a remote sales tax system, eliminating strict SSUTA membership would force Congress to regulate Internet sales

${ }^{83}$ Marketplace Fairness Act of 2013, S. 743, 113th Cong., § 2(a), (b) (2013).

Pitt Tax Review | ISSN 1932-1821 (print) 1932-1996 (online) DOI 10.5195/taxreview.2013.17 | http://taxreview.law.pitt.edu 
taxation utilizing its own power and authority to regulate interstate commerce.

Returning to the concept of the "small seller exception," which was left completely undefined under both the Main Street Fairness Act and the SSUTA, Congress should establish a clear and concise definition for the "small seller exception." Once again, the ability and reasonableness of including such a provision is apparent in the Marketplace Fairness Act of 2013. ${ }^{84}$ The Marketplace Fairness Act states that "[a] State shall be authorized to require a remote seller to collect sales and use tax ... if the remote retailer has gross annual receipts in total remote sales in the United States . . exceeding \$1,000,000." ${ }^{\prime 5}$ If Congress does not wish to establish a clear definition for a "small seller exception," it must, at the very least, provide actual intelligible standards to adequately guide a delegated entity in defining such an exception. If delegation of authority to define the small seller exception is granted to the SSUTA Governing Board or some other entity, such intelligible standards will be necessary to protect the interests of remote retailers from abuse or partiality by the delegated entity. Moreover, without these intelligible standards, proposed legislation will continue to be subject to challenges under the delegation doctrine.

While the Marketplace Fairness Act of 2013 picks up the slack in areas where the Main Street Fairness Act was severely lacking, it is not flawless. Although the Marketplace Fairness Act removes the strict obligation to adopt and comply with the SSUTA, and although it provides requirements for this method of compliance, ${ }^{86}$ these requirements are not defined well enough to assure uniformity in interstate compliance. This lack of welldefined compliance standards is comparable to that found in the Main Street Fairness Act. The Main Street Fairness Act permitted Congress to take the easy way out by letting the SSUTA Governing Board more fully define the standards that authorize state Internet sales tax collection. It is, therefore, recommended that Congress institute the same minimum

\footnotetext{
${ }^{84}$ See supra note 58 and accompanying text. While the adoption of the Marketplace Equity Act is not within the purview of this Note, it too defined the "small seller exception." See Marketplace Equity Act, H.R. 3179, 112th Cong., § 2(b)(1) (2011).

${ }^{85}$ Marketplace Fairness Act of 2013, S. 743, 113th Cong, § 2(c) (2013) (emphasis added).

${ }^{86}$ See id. § 2(b).
}

Pitt Tax Review | ISSN 1932-1821 (print) 1932-1996 (online) DOI 10.5195/taxreview.2013.17 | http://taxreview.law.pitt.edu 
requirements provided in recently proposed legislation, but with substantially more definition. If it is the intent of Congress to adopt the SSUTA requirements, then Congress should simply incorporate the exact language of the provisions in the SSUTA into the proposed legislation. While this action will take a little extra initiative on behalf of Congress, it would wholly eliminate the need to enforce parallel requirements under the SSUTA, avoid heavy reliance on a delegated entity, and, therefore, reduce the number of potential challenges and the corresponding costs and burdens of litigation.

\section{CONCLUSION}

Pursuant to the decision in Quill Corp., Congress is provided the opportunity to overrule the substantial nexus requirement for remote retail transactions. Although the Marketplace Fairness Act of 2013 is the only Internet sales tax bill currently under review by Congress, future proposals are likely to be made, including a reintroduction of the Main Street Fairness Act. Lessons must be learned from the Main Street Fairness Act to prevent challenges under the delegation doctrine including Congress delegation to the private entities and a lack of intelligible standards to direct the decisions made by such entities. Since the strict requirements to become a member of the SSUTA and submit to the SSUTA Governing Board are likely to spur serious litigation regarding delegation, it is recommended that Congress utilize its power to regulate interstate commerce and enact legislation that provides well-defined state compliance provisions and the "small seller exception." This solution is both reasonable and feasible given certain provisions in the Marketplace Fairness Act. The adoption of a more defined Act will surpass previously proposed resolutions to the current Internet sales tax issue, as it will be grounded in the best scenario for Congress' desire to alleviate the burdens on interstate commerce, the states' concern for receiving revenue from Internet sales transactions, and remote retailers who can be assured that Congress shares their interests in alleviating the burdens of multi-state sales tax collection, while altogether reducing the financial and efficiency costs brought by delegation challenges.

Pitt Tax Review | ISSN 1932-1821 (print) 1932-1996 (online) DOI 10.5195/taxreview.2013.17 | http://taxreview.law.pitt.edu 